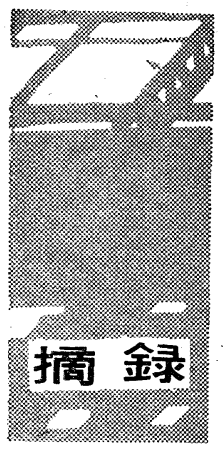

採 鉱・探 炭

\section{1）密閉された集中装薬による 岩石の破壊}

Wilbur I. DUVALL and Thomas C. ATCHiSON: Rock Breakage with Confined Concentrated Charges (Mining Engineering, Vol. 11 No. 6, 1959, pp. (0.5 611)

この論文は，密閉された集中装薬による岩石の破壊過 程を,主として物理的な見地から検討するために,USBM の行のた箺験結果立びにとれらについての考察に関して 報告したものである。

本論に入る前に，一次元的な岩石試料を用いての従来 の研究結果を紹介し,さらにこれらの室内穾験の結果が, 密閉状態で行われる穿孔発破の破壊過程の説明沉は直接 応用し得ないことを指摘し，密閉集中装薬による破壊過 程を究明し，ょた破壞に及ぼすガス膨脤の影響の程度を 検討するためにこの実験が行われたことを述べている。

実駼は, 花崗岩・砂岩・泥灰岩・チヨークの 4 種の岩 石を対象として，簡単なクレータ・テストによつて行わ れた。岗る一定量の装薬では, 装薬深さがある一定限界 までは，装薬深さ海しいか女たはそれよりるやや深い 目のクレータを生じ，装薬深さがその限界を越して深く なれば，常に装薬深さに比へて浅いクレータを生じ!。 このような装薬深さよりる浅いクレータでは, 爆心とク レータ带との中間に介在している岩石には何らの損傷も 与克ないで, 爆心からクレータ带までエネルギが伝達さ 机たことを示している。しかしこの場合は，穿孔を通じ て生成ガスがエネルギを伝達した可能性も考光られるの で，予想されるクレータ帶には呀孔せず，チョークから 成る二自由面の一面加長孔を穿ち，先の長さを最小抵 抗線よりも遥か汇長くして，旁の先端装薬深さよりも 浅い深さのクレータの结じ得るに足る䁷の装薬をして実 験が行われた。その後爆心とクレータの中心を通る面で 切断して破壊状況を調べた結果, 地表面には浅いクレー タ, 爆心の周りに粉砕圈, そしてその中間梳いくつか のキ裂沙生成されていることがわかつた。これらの結果
から，爆心とクレータ带の中間にはな技わされないし

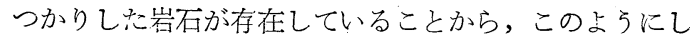
て地壵面に生じたクレータは，ガスによるェネルギによ つて生成されたものでなく，爆心からの何らかの波動仙 よつて伝達されたェネルギによつて生成された確証であ ると述べている。

次に装薬が岩石中で爆ごうした際に生成される波動㐳 ついての研究を述べている。このため記哔されたスト レン・ゲージ並びにその記録装置について詳しく述へ, 花㓏岩・砂岩中で得られたヒズミ記録を解説している。 それによると爆破点近傍のヒズミ波は，迅速な立上りと 比較的ゆつくりした下降を示す単一波形の正縮パルスを 呈することが特徵で，伝播距離が増すにつれて振幅は急 激に減衰し，パルスの波長が伸びてくるとともに僅かの 張力位相が現われてくる。そして岩石の種類が異なれば， ヒズミ・パルスの大きさ非状に大きく影薌してくるが， 薬種による羙は余り顕著ではないことを指摘している。 これらのヒズミ記録は種々の爆破条件並びに爆源距離に 対して求められているが，その結果を詳細㰸討するた めに，七ズミ波の走行距離や時間を装薬量の立方根で除 した一定の尺度を設け，このようにして装薬量の影響を 消去した尺度を使うことによつて，距離とヒズミの值と の関係，距離と走行洔間との関係などの基本的な関係を 求め, これらを使つて装薬深さとクレータ深さとの関係 を計算し，その值を笑測值と比較しつつ，種々の装薬深 さに対灾して生ずるクレータ深さの問題を，スラブ生成 の機構と関連させて考察している。

さらに岩石の動的な破壊ヒズミの大きさをヒズミ記録 から推定する方法を述べ，このようにして推定された動 的な引張破壞七ズミは，実験窒で求められた静的な引張 破壊七ズミの值よりもやや大きいことを指摘している。

また砂岩に対して行ったクレータ・テストでは, 導体 簿の小片を予想さ礼るクレータ表面の種々の位置に同心 状に貼りつけておき，これを電気回路に接続しておいて， 岩盤表面の破壊と同時汇管が切断され回路が断たれるこ とを利用して，爆ごらの後岩石表面の破断されるまでの 時間を測定するとともに，これとヒズミ・パルスの走行 時間之の関係を検討している。その結果，装薬深さが極 めて深いとき拈よびクレータ中心から極度に離れた䇴の 場合を除いては，いずれる岩石の破断はヒズミ・パルス のピークが到達してからやや扔くれ，さらにヒズミの下 降時聞の半分が経過するまで沉生でていることを指摘し ている。

また別て砂岩に対する実験では，3,000 コマ/sec の高 速度撮影を併用し，岩石の破断の際の種々の現象を観察 している。とくに装薬深さが適当で標準的なクレータを 生成する場合の現象としては，むず垻塞物で每る砂の突 
出が見られ，ついで爆ごうガスが突出する。表面にキ裂 が現われると同時に破断された岩石が上部汇飛び出し， これらはガス雲のもとで活とんど完全汇近い半球状のド 一ムを作るが，岩石ドーム中のキ裂から飛び出してくる ガスは活とんぞ見られない。中心部の方から押し出して くる岩石は細かく砕かれドームを形作るまで沉至らな いなどのことを指摘し，さらにこのようなドームを作つ ている岩石は一定速度をもつているが，これが棒質的に 水平成分を欠いているといらことが，破断岩石片が膨脹 ガスによつて押し出されたるのではないという確証であ ると説明している。またこの際の岩石速度とヒズミのピ 一ク值から計算に上つて求め粒子速度とを比較し，両 者がかなりよく一致するとい5ことも，大部分の岩石破 断が自由面に扔汁るヒズミ・パルスの反射の結果生じた るのであるといら考觉を裹付けるものであると結論して いる。

(伊藤一郎)

\section{2）ハリケーン砂鉄鹆の研究}

H. C. GRIMSHAW \& J. T. BURDEKIN : Tests of the Hurricane Stemmer (Safety in Mines Research Establishment, Research Report No. 157 (1959))

痋発雷管が普及して, 岩石坑道掘進の場合等には，1 ラウンド 20〜70 本もの爆破孔のタンピングを行うよう になつた。このように多数のタンピングを, 従来通りの アンコを込棒で押し込むやり方で処理する之， 1 時閒半 もの時間を消費する。この作業は, 王さく空気で, 砂状の 物質を吹き込む方法により機械的汇行うことが出来る。 いわゆる砂鉄砲で，英国では 20 年も前から“ハリケーン 砂鉄胞”という名で笑用化している。

このハリケーン砂鉄㿣汇よるタンピングの実験を行 い，広範な基礎的な知識が得られた。この実験は図のよ うな砂鉄盷を用い，坑内の現場試験とコンクリート・ブ ロックの爆破孔炕る实験室試験により行われた。試験 江用いた充填材料は，数種の砂 $(-10 \sim+70$ B.S.S.* 80 $\%$ 以上), 砅 $(-5 \sim+30$ B.S.S. $90 \%)$, 石灰石グリッ 卜 $(-5 \sim+30$ B.S.S. $)$ で, 試験は

1、圧気による孔込め汇影響を与兄るファクター

2. 粉栕の発生

3. 静電気の発生

の3 項目について行われた。結論だ汀を以下にまとめた。

1. 砂鉄跑のバイプ (injector tube) の長さは, 出ま り長過禁ると取扱いに不便で，また，孔口から吹き込む 上了にすると充填が不均等になる。6ft 爆破孔の場合に

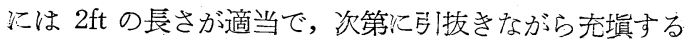
と良い結果が得られ苋。

2. パイプの太さは，太過ぎると孔壁との間炏砂がつ

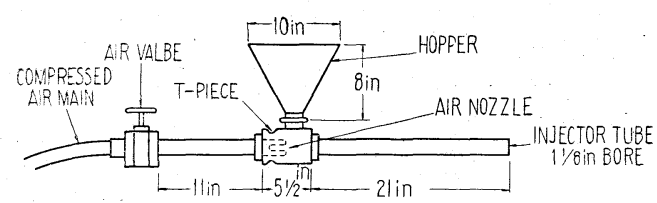

第1図ハリケーン秒鉄砲細部

まつて抜けなくなる。間隔として $1 / 4$ in 以上が必要であ る。

3、ホッパーの大きさは，遅滞なく充填出来るだけの 砂を入れる大きさが必要で（西る炭坑で行つた例では， 1 本充填するのに約10秒を要した）あるが，岕まり大き くすると不便である。

4. 孔込めの速度は, 充塤材が粗い程, 乾燥している 程大きい。水分 $3 \%$ 上!上沈なると，バイプのつまる場合 が生がる。

5. 空気压力は 90 〜 lb/in² で用いれるが， $60 \mathrm{lb} / \mathrm{in}^{2}$ 以上であることが望ましい。

6.ビニール被覆の雷管脚線は, 充填材が特別温大 な粒子を含まない限り，吹き付けによつてほとんど摩粍 することがない。したがつて絶縁不良にならない。綿巻 線は幾分弱い。また，キンクしたところは，より傷つけ られ易い。

7. 装薬と孔壁との間は，砂粒で充填されることも市 り，されない場合も市る。薬包は動かない。薬包同志の 閒陵も，砂がつまる時とつまらない時とある。

8. 爆破孔を横切る割目は㘯る程度充媜される。

9. 麼埃の発生を防ぐためには，2３\%以上の水分を 含むことが望ましい。

10. 高速の微粉子が带電するため, ある条件の下でー 一実際には極端に起りにくい.-は，パイプ (injector tube）は非常に高いボルトの電気を带びる。実験では 18,000 Volt にも達した。パイプにある電気容量が付加 されると, 蓄わ兄られる電気量は低感度雷管を起爆し， メタン混合気を爆発させる汇足るエネルギーとなる。

11.こうした危険は,パイプの絶縁抵抗法配される。 絶縁抵抗が $40 \mathrm{M} \Omega$ 以上でも, 带電压は局限される。

12. 充填材が僅かの水分（1\%以下）でも含んでいれ ばこのような带電は起らない。大気中の水分によつても 帯電の漏洩が起る。

13. 充填材には $1 \%$ 前後の水分を含をせ, 伝導性 (antistatjc)空気ホースを使うことが望ましい。(山口梅太郎)

\section{3）坑内の地圧变化の測定}

E. R. Leeman: The measurement of changes in rock stress due to mining (Mine \& Quarry Engineering, July 1959. S300 304)

Witwatersrand の金山はすでに地表下 11,000ft の深 
さに達している。その結果，地熱と地压に対する対策が 重要楞題となつている。前者注適当な通気をぼ゙こすこ とにより解決されるが，後者は高地厓の結果生ずる岩八 ネに対して切羽定安全保護してやらなけれ和ならない という重要性を有している。南阿理工学研究死議会 (South Africa Council for Scientific and Industrial Research）では鈗山会社を共同で，この問題の矵究を 開始した。現在の研究はとくに，坑内切羽の周国岩石の 范力変化を測定することにしばつている。

岩石内の七ズミ変化を測定する 1 つの方法汇岩存内に 呀孔されたボアホールの直径の变化を測定する方法が出 る。この場合ボアホールは龟裂の存在しない岩石内に呀 孔されていなけ秃ばならない。この方法で岩不の応力変

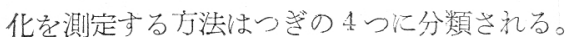

(a）ボアホール内壁に接着されたストレンドージに よを方法。

（b）ボアホール内に固定されたヒズミ測定装置学使 用与る方法。

（c）水力カプセル型測定器を使用する方法。

（d）ボアホールの值径变化を測定する琶置定用らる 方法。

この雑誌に Mohr がすでに記述している方法，すな わらがアホール底面に久トレンダージを接着する方法快 （a）飞属する。ゲージ接青面の外周にスリッ卜学切り

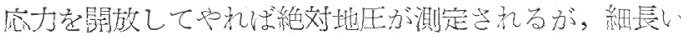
ボアホールの底面にストレンダージを接着するというこ とと，゙゙ージを防湿せしめるこ之が現場的心見て困難 であることが多い。（））漏するものとしては Bucharan, Marsh, Thurston その他力ナダ鉱江骨員沼上る

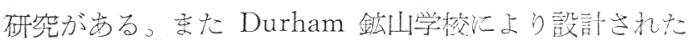

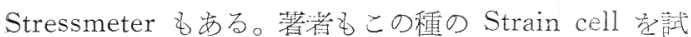
作した。しかし，測定器をボアホールの内で完全にセょ ントで固結することの困難なこと，セメントを周聿岩石 と同一性質のもの上な乙得ないこと，るとの応力状熊を 再現し得ないこと，ボアホール内の埋設状態党確認し得 ないこと，引張穴力は㵋定し得欢こと，关の他の理由か らこの方法を放集した。(c) に鹰するものに Potts と Cumpsty の装置（ゴム水力カプセル型測定器）が岁る
が，これは水平応力が測定されない。

このような理由から Witwatersrand 研究チームでは ボアボール直径の微小变化の測定に努力を傾注した。 Maihak cell が試験の結果，有效で少ることがるかか た。宫た著者は 1 1 2 in の直径のボアホール内で測定し 得る strain cell（付図）を試作した。こ礼では垂直更 び水平成分の変化を測定し得る。困で $3,4,5,6$ 法ワイ ヤストレンゲージでステンレススチール環 2 亿接着され ている。7,8 はピンでボアホール内で自由にケーシング 9 を通過乙滑動し得る。11はギャー・ボックス，12,13 はギャーでこれらは小型 D.C.モーターにより回転さ 机它の結果，7,8 のピンは将アホール内壁上接触する。

それによりボアホールの变形は環上のストレンゲージ の抵抗变化となり現れるのでストレンタータが自記計に 接続され測定される。14,15 快鋼製スりッパーでボアホ 一ル内測定器を定置させて拈くためのるの。1は多ブ ルニニバーサルジョイントで他のニニット学接続する。

カリブレーションは寒験室内で既知の变形を加光て行 5。(鈴木光)

選鉱・選炭

\section{4) コンディショナにおけるパルプ の滞留時間}

E. C. Gibson and G. G. Eichholz: Radioactive Testing of Aerator Tank Performance, Department of Mines and Technical Surveys, Ottawa, Mines Branch Research Report R. 18, 10 pp. ; (Mining and Quarry Engineering, March 1959 143 144)

Ottawa の鉏山局選鉣製鐇部で行つた銅鉱のパイロッ トプラント处理において, パルプ濃度が急変すること, 怙よび浮選成績が悪いことから，コンディンョナ（aerator tank) 中に抢沙る空気混和の接触時閒が，計算通 り汇行つていないことが明らかとなつた。无こで故射性 洎跡子 $\mathrm{Ag}^{110}$ を用いて，パルプ滞留時間の測定を行な つて見た。銀の同位元素を選えた理由は，无れが浮選条

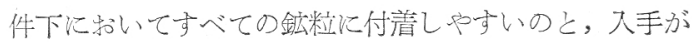
容易だからで㐫る。

主として短絡（short-circuiting）の程度定眀らかに するために，次の上らな手順て骵験索行なつた。西らか
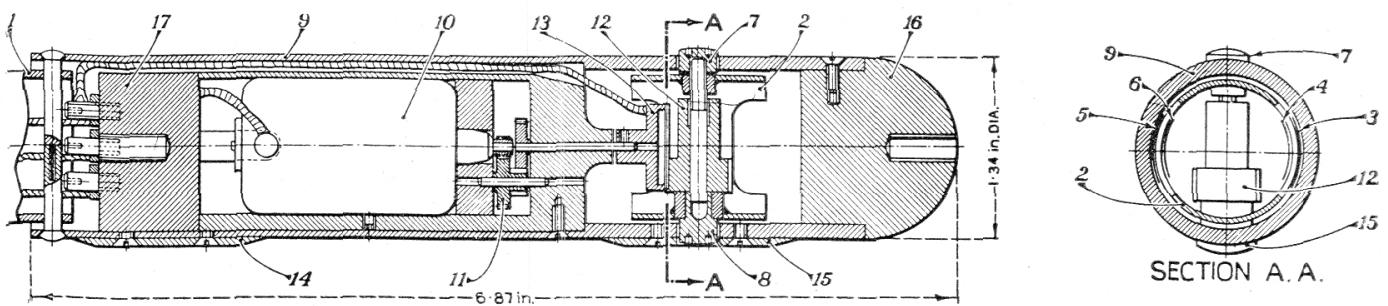

第 1 図 
じめ放射性の硝酸湌を加えておいた少量のスラリーをコ ンディショナの給鉱口に注入する。一定時間毎に試紏を 出口管から採取し, シンチレーション・カウンタで放射 能の強さを測定する。そして計数の対数に経過時間との 関係をグラフにプロットする。

1 回の試験に使用したアイソトープ $\left(\mathrm{Ag}^{110}\right)$ は 0.1 ミリキューリー(価格 40̀cent), コンディショナはデン バーのエア・リフト・ミクサ型 (容量 $\left.1.2 \mathrm{~m}^{3}\right)$ ，フィー ド量は $0.23 \mathrm{t} / \mathrm{hr}$ である。

空気を吹さ込んだ定常状態に沶いて，2 回測定を行な い，第 1,2 四に示す結果を得た。これらのグラフで認め られるように, はじめ短時間の鋭いピーク（短絡の著し いことを示す) があり，つぎに緩やかな隇衰が起つてい る。短絡の主な原因はフイードパルプの下向きの流れが 压縮空気の上向きの流れによつて妨げられること西る のではないかと思わ机たので，空気吹込反を止めたとこ ろはじめのピークはなくなつた（第3図）。そこでェ ア・パイプをタンクの側壁へ配置換觉することにようて， 短絡をなくすことができた（第4 図）。この配置換光の 前にはパルプの74\%が短絡していた勘定になる。

公称滞留時間はフィード量に対するタンク容積の比と して一般に計算されている。フィード髤を $0.23 \mathrm{t} / \mathrm{hr}$ ，パ ルプ濃度を $25 \%$ ，タンクの容量を $1.2 \mathrm{~m}^{3}$ とすれば，公称 滞留時間は98min となる。この計算法では均一な流れを 前提としているので㐫るが，実際にはそうでないから，
上に述べたような測定を行ない，放射能曲線の傾斜から 有效滞留時間を計算する方がよ心。平均有效滞留時間は 放射能がはじめの 厉に下るまでの時間から計算できる。 計算の結果, 短絡が起つている場合の滞留時間は1.3min であるが，短絡が起つていない場合は 108min で，公称 值に近い值と宗つた。

これらの試験の結果, タンク中の流れ模様は予想して いたよりもずつと複雑であることがわかつた。エア・パ イプの配置換宎の前に認められた $1.3 \mathrm{~min}$ 間の短絡流れ のほか, タンクの外壁に沿つて上昇し, 中心パイプを通 つて下降する。平均滯留時間 108min の粒子のらせん運 動をもたらす定常渦が存在している。さらに 5 6 $\mathrm{min}$ の困難をもつ単純なループ回路も存在し, したがつて粒 子はタンク内に滞留している間汇平均 18〜25 回上下し たことになる。(井上外志雄)

\section{冶金}

\section{5）銅ニッケル鈹の湿式冶金的処理}

В. П. Говоров : Цветные Метал. 32 [2] 41 46, 1959

オートクレーブを用いないて銅ニッケル鈹を硫酸で選 択的に浸出する方法について研究した。 $\mathrm{Fe}$ と $\mathrm{Ni}$ の選 択的分離は，操作を 2 段とし，浸出液を问流させて行つ た。第工段では第段の浸出液をるつて鈹中の Fe を
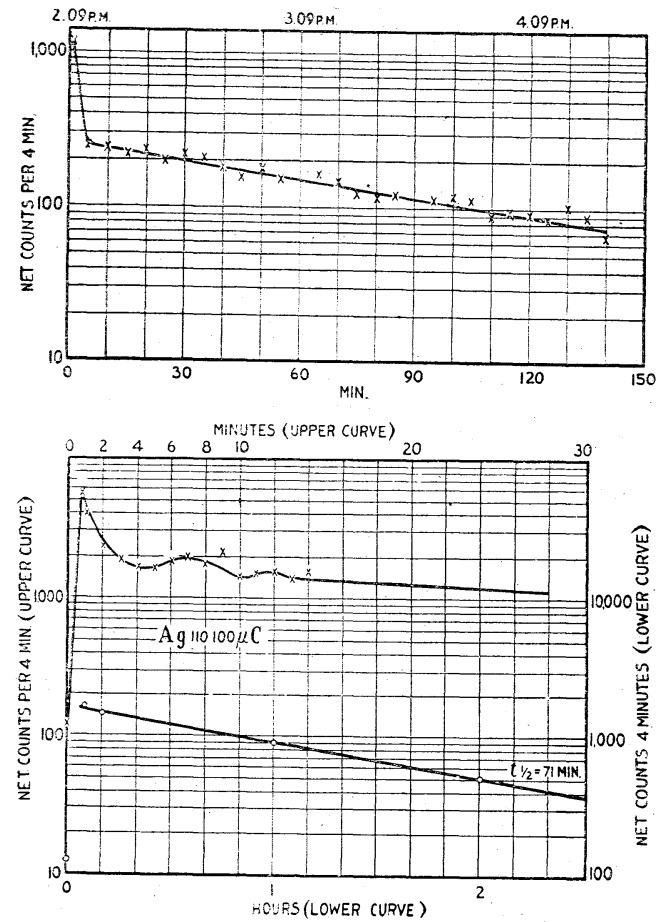

第 1 ～図の縦軸络 4 分間当 りのカウント数, 横軸统時間

第3 図 流出パルプの放射能 の時間的変化（エア パイプを配置換えし た後)

\section{$\uparrow$ 第 1 図}

\section{世第 2 図}

流出パルプの故射能 の時間的変化 (エア・ パイブを配置換えす る前)
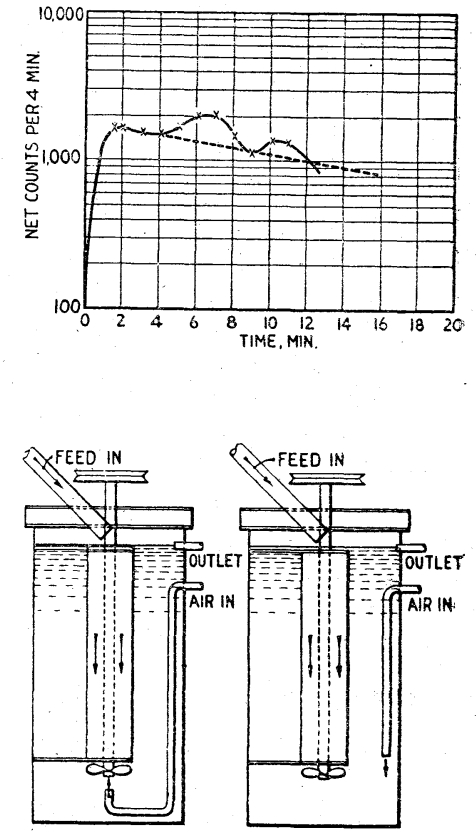

第4 図 左は改造前，右は改造後 のコソデイショナ 
$\mathrm{FeSO}_{4}$ の中性溶液の形で溶出, 第正段では新たな $\mathrm{H}_{2} \mathrm{SO}_{4}$ によつて第 I段の残渣を浸出する。第I段からの溶液中

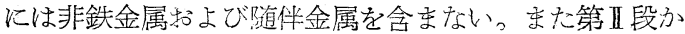
ら溶出される液中汇は $\mathrm{Ni}$, Co 拉よび残余の $\mathrm{Fe}$ が含ま れるが $\mathrm{Cu}$ 拈よび随伴金属を含まない。これら2段の 操作汇よつて得られる残渣汇は $\mathrm{Cu}$ 之事実上すべての随 伴金属が含穒孔る。銅ニッケル鈹の硫酸溶液処理によつ て硫化銅を分離する方法，あるいは $\mathrm{Fe}, \mathrm{Ni}$ を分離する

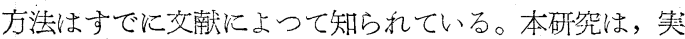
際の操業炉汇よて得られた各種の $\mathrm{Cu}-\mathrm{Ni}$ 鈹㧍よび鈹 蛒和物について鈹成分組成の検査，Fe と $\mathrm{Ni}$ の選択的 分離の可能性衫よび主として貴金属つ挙動てついてしら ベた。

原料沾よび製造工程つ異なる紴（冷鈹）の組織をX線 回折ならびに化学分析によつて検査した結果， $\mathrm{Cu}-\mathrm{Ni}$ 鈹を冷却する際に現初剠る相は銅つ硫化物 $\left(\mathrm{Cu}_{2} \mathrm{~S}\right), \mathrm{Ni}$ の硫化物(ペントランダイト), 多量の $\mathrm{Ni}$ 硫化物 $\left(\mathrm{Ni}_{3} \mathrm{~S}_{2}\right)$ と硫化鉄（ピロタイト），マグネタイト， $\mathrm{FeO}$ で斑銅鉣 は認められなからた。また，S 含有量の高い鈹（S 29\% 以上）には黄銅鉣が現われた。この黄銅鉱を除けば酸に 不溶の Fe 硫化物, Ni 硫化物はない。

実験汇用いられた鈹（墩造条件を異にする）の成分と それらの浸出結果を表沈示す。鈹を0.104〜0.074 $\mathrm{mm}$ の

第 1 表 鈹の製造条件と成分

\begin{tabular}{|c|c|c|c|c|c|c|c|c|c|c|c|}
\hline \multirow{2}{*}{ 鈹 No. } & \multicolumn{5}{|c|}{ 調 合 物 熔 解 量 $(\mathrm{g})$} & \multicolumn{2}{|c|}{ 産 出 鈹 } & \multicolumn{3}{|c|}{ 成 分 $(w t \%)$} & \multirow{2}{*}{$\begin{array}{l}\text { 製造 } \\
\text { 条件 }\end{array}$} \\
\hline & 鈹 238 & 転炍鉦 & 金属 & $\mathrm{Cu}$ & $\mathrm{Fe}$ & $\mathrm{Cu}$ & $\mathrm{Fe}$ & $\mathrm{s}$ & $\mathrm{Ni}$ & Co & \\
\hline 480 & t & & - & - & - & 7.5 & 50 & 27.5 & 11.0 & 0.45 & \\
\hline $480 \mathrm{~A}$ & & & - & - & - & 7.5 & 50 & 27.5 & 11.0 & 0.45 & \\
\hline 570 & & & - & - & - & 12.7 & 35.7 & 26.5 & 18.8 & 0.35 & 省 \\
\hline 238 & - & & - & - & - & 15.2 & 43.2 & 32.6 & 7.52 & 0.18 & \\
\hline $225 \mathrm{~K}$ & & & - & - & - & 15.2 & 43.2 & 29.3 & 8.0 & 0.19 & \\
\hline 517 & 165.7 & 31.5 & & - & - & 13.0 & 47.4 & 25.6 & 7.44 & -1 & \\
\hline 518 & 137.1 & 31.4 & & 26.0 & t & 22.6 & 38.2 & 24.12 & 5.68 & & \\
\hline 520 & $2 ; 0.0$ & & - & - & 27.0 & 11.7 & 51.5 & 27.3 & 6.84 & & \\
\hline 576 & 100.0 & & - & - & 5.0 & 13.5 & 47.9 & 23.9 & 6.9 & & 略 \\
\hline 577 & 100.0 & & - & - & 7.0 & 14.5 & 48.3 & 27.6 & 7.4 & - & \\
\hline 500 & - & & I & - & 1 & 16.16 & 47.1 & 27.3 & 9.0 & 0.23 & \\
\hline
\end{tabular}

第 2 汬 浸出結果 $\left(\mathrm{H}_{2} \mathrm{SO}_{4} 200 \mathrm{~g} / \mathrm{l}\right.$ 溶液で浸出 $)$

\begin{tabular}{|c|c|c|c|c|c|c|c|c|c|}
\hline \multirow{3}{*}{ 鈹 No. } & \multicolumn{4}{|c|}{ 溶液中へ $\mathrm{Fe}$ 抽出 } & \multicolumn{2}{|c|}{ 溶 液 中 } & ^ & $\mathrm{Ni}$ 抽 & 出 \\
\hline & \multirow{2}{*}{ 抽出率\% } & \multirow{2}{*}{ 残㴪中\% } & \multicolumn{2}{|c|}{ 溶 液 中 $\mathrm{g} / l$} & \multirow{2}{*}{ 抽出率\% } & \multirow{2}{*}{ 残渣中\% } & \multicolumn{3}{|c|}{ 溶 液 中 $\mathrm{g} / l$} \\
\hline & & & $\mathrm{Fe}$ & $\mathrm{Ni}$ & & & $\mathrm{Ni}$ & $\mathrm{Fe}$ & Co \\
\hline $4 \varepsilon 0$ & $97 \sim 98$ & $2 \sim 4$ & 103 & $0.0 \sim 0.3$ & 81.0 & $6 \sim 10$ & $45 \sim 50$ & $4 \sim 5$ & $1.5 \sim 3$ \\
\hline $489 \mathrm{~A}$ & $93 \sim 99$ & $0.5 \sim 1.5$ & 100 & 0.0 & 9รว 98 & $0.5 \sim 2.0$ & $50 \sim 60$ & $3 \sim 4$ & $2.5 \sim 3$ \\
\hline 570 & $75 \sim \varepsilon 0$ & $|10 \sim 12|$ & $70 \sim 80$ & 2.0以下 & 75 & -1 & 30 & 8.5 & \\
\hline 238 & & 数 & 值 が & 备 だ & 小さい & & & & \\
\hline $225 \mathrm{~K}$ & 93.0 & $10 \sim 12$ & $78 \sim 85$ & $0.6 \sim 1.0$ & 65 & & 26 & 10 & \\
\hline 517 & 98 & $1.5 \sim 3.0$. & 100 & 0.0 & 55 & $10 \sim 15$ & 11.0 & 1.42 & \\
\hline 518 & 98 & $1 \sim 2$ & 10 & & 85 & $5 \sim 10$ & $28 \sim £ 0$ & $3 \sim 3.5$ & \\
\hline 520 & 99 & $0.5 \sim 1.5$. & 10 & 0. & 95 & $0.5 \sim 1.5$ & $20 \sim 35$ & $1.5 \sim 2.5$ & \\
\hline 576 & 93 & 12 & 15 & & $\subseteq 0 \sim 95$ & 検 & 定 せ & ず & \\
\hline 577 & 99 & 1 & 10 & & $50 \sim 95$ & 3.7 & 検 定 & せず & \\
\hline 500 & 99 & $0.5 \sim 1.5$ & 100 & 0.0 & $95 \sim 93$ & $5 \sim 4.0$ & 60 & $1.5 \sim 4.0$ & $0.4 \sim 0$ \\
\hline
\end{tabular}

大ささに粉砕, 復水器付のレトルトに入れて $100 \mathrm{~g} / l$ $200 \mathrm{~g} / l \mathrm{H}_{2} \mathrm{SO}_{4}$ 溶液で浸出。浸出温度は溶液の沸点より 若干低めの温度。浸出時間は第 I 段 1 時間, 第 II 段 2 4 時聞。浸出結果から次のことがい党る。操業炬によつて 得られる鈹は $\mathrm{Fe}, \mathrm{Ni}$ の選択性が悪く湿式治金的処理に は不適である。還元雲囲気中で再愹解した鈹は適する。 この選択性は鈹中性に含有するマグネタイト量に関係し， その量が少ない漂ど選択性が良い。，亲た鈹中に黄銅鉣を 含有する貱は处理不適である。すな方ち，湿式処理の可 能な鈹は $\mathrm{Fe} / \mathrm{Ni}$ の值が 3.5 上り小でなく, $\mathrm{S}$ 含有量が $29 \%$ より高くなく，マグネタイト含有量が $2 \%$ 上り多く ない場合である。

各鈹について中間沈澱物中からの Fe の溶解速度と中 間溶液からの $\mathrm{Ni}$ の沈激速度との関倸をしらべた。また 鈹試料 500 について実際处理の堤合の物量計算を行つ た。[交献数 5 ]。(鈴木隆三)

\section{6）鉄釷石の苛性ソーダ溶液から 電解鉄粉の製造}

J. A. M. LeDuc, R. E. Loftfield and L. E. Vaaler: Electrolytic Iron Powder from a Caustic Soda Solution (J. Electrochem. Soc. vol. 106 (1959) No. 8, 659 667)

$\mathrm{Fe}(\mathrm{OH})_{3}$ は濃厚な $\mathrm{NaOH}$ 溶液にある程度可溶性で 㐫り，その電解によつて金属鉄粉を 製造することが出来る。本法に関し て Estelle ${ }^{1)}$, Angel ${ }^{2)}$ および Mehl3) の特許が劣るがをだ余り注目されて いない。乙か乙本法は鉄鉱石から容 易汇直接鉄粉を製造し得る方法とし て興味がある。本論文は本法二電解 条件，笑収率和よび鉄粉の性質につ いての研究結果を述べたものであ る。

\section{1. 基礎的研究}

等量の $\mathrm{H}_{2} \mathrm{O}, \mathrm{NaOH}$ およよ゙微粉 の化学的純料 (C.P.) な $\mathrm{Fe}_{2} \mathrm{O}_{3}$ か らなる電解液を陰極電流密度 30 〜 $90 \mathrm{Amp} / \mathrm{ft}^{2}, 120^{\circ} \mathrm{C}$ て鉄弯仙はニッケ 儿擎容器を陽極，軟鋼板を陰極と乙 て電解したところ，金属鉄とともに 酸化物が多量陰極に付着するので亮 速伯の回転翼を使用して粘性のある

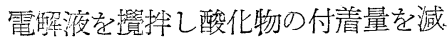
少させることが必要となつた。空気

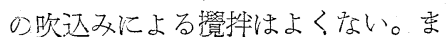
た鉄製陽極は電解中徐々に腐蝕され るのでニッケル陽極がよいことも明 
らかになつた。

電解液の安定性一一新らしく製造した液の電流効率 (C.E.) は電解を継続すると次第に減少する。例党ば電 解開始後の数時閒は C.E. 90\%であるが $24 \mathrm{hr}$ 後では C.E. は次第に 60 80\% に低下する。新夜の C.E. が 高いのは $\mathrm{Fe}_{2} \mathrm{O}_{3}$ を $\mathrm{NaOH}$ 液に添加すると速やかに溶 解する易溶性の部分があることによるのであろう。また 新液からの析出物は粗大な粉末であるが電解時間の経過 とともに次第に緻密なるのになる。

液温— $\mathrm{NaOH} 200 \sim 600 \mathrm{~g} / \mathrm{l}, \mathrm{Fe}_{2} \mathrm{O}_{3} 25 \sim 75 \mathrm{~g} / \mathrm{l}$ の電解 液, 陰極電流密度 $40 \mathrm{Amp} / \mathrm{ft}^{2}$ で $39 \sim 120^{\circ} \mathrm{C}$ の範国で温 度の影響を実験した結果 $\mathrm{NaOH}$ の濃度如何に関せず最

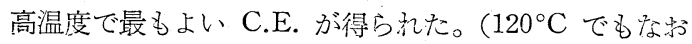
液の沸点以下である。）ま沈温度が上ると析出する樹枝 状晶は大きくなつた。 $35^{\circ} \mathrm{C} て ゙$ て析出したものは小さい樹 枝状晶が集合していて流動速度が悪くフルイを通過しな

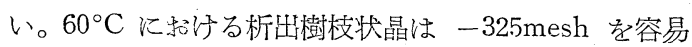
に通過する。さらに高温になると幾分かの樹枝状晶は -325mesh を通過しないので粉研する必要がある。乙 かし流動率は高温になるほどよくなる。9 $90^{\circ} \mathrm{C}$ 程度の温 度が C.E. を高く保ち，かつ粗大な樹枝状晶を析出する ため望をしい。

$\mathrm{NaOH}$ の濃度—C.E. が50\%以上であるためねは $400 \mathrm{~g} / /$ 以上の $\mathrm{NaOH}$ が必要である。 $200 \mathrm{~g} / l$ の $\mathrm{NaOH}$ では, $\mathrm{Fe}_{2} \mathrm{O}_{3}$ の全量 $(50 \mathrm{~g} / l)$ を溶解乙得ない。 $\mathrm{NaOH}$ $-465 \mathrm{~g} / /$ の時は C.E. 約 $55 \%, \mathrm{NaOH} 765 \mathrm{~g} / /$ の時は C.E. 約70\%である。C.E. をよくするためには 600〜800g/l の $\mathrm{NaOH}$ が必要である。

$\mathrm{Fe}_{2} \mathbf{O}_{3}$ の濃度— $\mathrm{NaOH} 400 \sim 765 \mathrm{~g} / l, 90^{\circ} \mathrm{C}$, 陰極電 流密度 35 40Amp/ft 2 で $25,50,70 \mathrm{~g} / l$ の $\mathrm{Fe}_{2} \mathrm{O}_{3}$ の範团 では $\mathrm{Fe}_{2} \mathrm{O}_{3}$ の濃度は電解に余り影響がない。 $\mathrm{Fe}$ は恐 らく溶液中の可溶性ナトリウムフェライトの還元により 析出するものと思われる。フェライトの溶解度は低いか らフェライトイオンの濃度を一定に保つに必要な最少量 の酸化物以上の存在は影響がない。ただし懸浮する $\mathrm{Fe}_{2} \mathrm{O}_{3}$ による定常的な補給がないとさには鉄の析出はま もなく中止する。 $\mathrm{Fe}_{2} \mathrm{O}_{3}$ の含有量が $86 \%$ の赤鉄鉣をC.P. な $\mathrm{Fe}_{2} \mathrm{O}_{3}$ の代りに用いると一般比 C.E. が 20 〜0\% 低下する。また磁鉄鉣を使用すると C.E. は $5 \%$ 以下に なる。

電流密度一一電流密变を大沉すると C.E. 々樹枝状晶 の大きさがこもに小になる。電流密度を増加することの 効果は高温にすることの効果と逆である。電流密度を増 大すると陰極被膜中の Fe の濃度を低下しそのために C.E. を減少し結晶核の数を多くして微細な樹枝状晶が 生成される。逆に温度を高くすると陰極被膜中の $\mathrm{Fe} の$ 粧散速度を大にし $\mathrm{Fe}_{2} \mathrm{O}_{3}$ の溶解度も大となる。その結
果 C.E. が大になり新らしい樹枝状晶を生成するよりも すでに存在する樹枝状晶の恙面に析出乙樹枝状晶は大き く生長するようになるのである。

\section{2. 中間工場試験}

電棤は厚み $0.125^{\prime \prime}$ のニッケル板盤で寸法 $18^{\prime \prime} \times 9^{\prime \prime} \times$ $29^{\prime \prime}$, 容量 20 ガロンで側面には液の装入口, 排出口があ る。電槽の側壁は 1 つ陽極で西り，この他電槽の中央

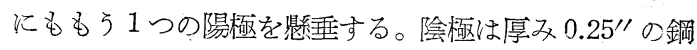

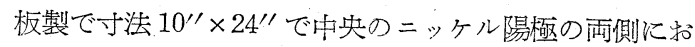
の打の 1 枚づつある。陰極の全面積は $5.5 \mathrm{ft}^{2}$, 直流電流 はセレン整流器により供給した。電槽電流は $275 \mathrm{Amp}$. 平均電槽電圧は約 $2.3 \mathrm{~V} . \mathrm{NaOH}$ の濃度は $50 \%$ で液量は 16.5 ガロン，電解中水分が蒸発するので週期的に水を 追加する。 $\mathrm{Fe}$ は最初 $9 \mathrm{lb} の$ C.P. $\mathrm{Fe}_{2} \mathrm{O}_{3}$ をたは鉄銗

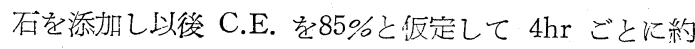
$2 \mathrm{lb}$ づつ補給した。液温 $85 \sim 90^{\circ} \mathrm{C}$ で電熱により外部加 熱した。液の攪拌は $1,000 \sim 1,500 \mathrm{rpm}$ の回転翼で行つ た。24hr ごとに陰極を取り出してよく水洗してアルカ リ和よび酸化物を除去して鉄粉を搔き落した。これを林 一ルミルで粉矿後さらに酸化物を除去した。鉄粉は乾燥 乙 120 mesh を通して科量した。C.P. $\mathrm{Fe}_{2} \mathrm{O}_{3}$ を使用す ると C.E. は 75〜80\%でめり， $\mathrm{Fe}_{2} \mathrm{O}_{3}$ の添加に上りそ の濃度が維持される限り液の特間的経過の影響は認めら れなからた。析出鉄粉は $\mathrm{Fe} 99.57 \%$ ，水素による重量

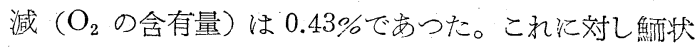
赤鉄鉱 (oolitic hematite) を使用すると C.E. は約50 \%で析出鉄粉も水素による重量減が $2 \%$ であり純度子低 い。析出物の性質も新しい間は陰極加ら容易に撜さ落せ たが冷却し乾燥すると困難防さたこれは恐らく析出 物を膠着させる珪酸塩の存在によるのであろう。しかし さらに研究して技術を改善したり適当な鉣不をを選べば相 当良好な結果を得るであうう。

な招この他に製造した鉄粉の粉末治金学的諸性質につ いて述べている。 (浅野梄一郎)

\section{参考文 献}

1) Estelle: スエーデン特許 42,849 (1915), 米国特許 $1,275,161(1918,4$ 月16日)

2) Angel: 米国特許 $2,622,063$ (1945,6月30日)

3) Mehl: 米国特許 $2,389,734$ (1945,11月27日)

\section{7）高い電流効率をもつマンガンの電解}

И. В. Яницкий и Б. Б. Стульпинас: Журнал прикладной химии 31 [2] 255 260 (1958)

マンガン塩溶液からマンガンを電着させる際には水素 の発生によつて電流効率の低下をきたす。従来の研究 （交献）によれば，硫酸程の電解液を用いた時つ電流効 
率は特別の添加剂なしで50〜60\%を超えない。ロダンア ソモン，亜硫酸をたは业酼酸坮などの添加によつて50〜 $70 \%$ 範囲まで高め得る。籍者等は亜セレン酸 $\mathrm{H}_{2} \mathrm{SeO}_{3}$ を添加した電解液について電解を行い, 電解液の組成, $\mathrm{H}_{2} \mathrm{SeO}_{3}$ の添加量牤よび陰極の電流密度が電流効率なら びに電着マンガン中のセレン含有量に扣よぼす影響を明 らかにし，一定した電流効率 90〜94\% で電着マンガン が得られることを示した。

装置方法：陽陰は織維で包まれ且つあらかじめある時 間使用されたもの; 陰極は銅, 鉄またはアルミニニーム の砢摩板 (両側の面積 $20 \mathrm{~cm}^{2}$ ) ; 電解液の容量 $250 \mathrm{~m} l$; 温 度 $18^{\circ} \sim 24^{\circ}$; 電解継続時間 $20 \sim 60 \mathrm{~min}$; 電流暴密度 $2 \mathrm{~A}$ $-\mathrm{h} / \mathrm{dm}^{2}$ 。

1) 一定濃度の $\mathrm{H}_{2} \mathrm{SeO}_{3}(0.15 \mathrm{~g} / l)$ の場合の電解液組成 と電流效率との関係: 電解液の成分 $\mathrm{MnSO}_{4} \cdot 5 \mathrm{H}_{2} \mathrm{O}$ 抒 よび $\left(\mathrm{NH}_{4}\right)_{2} \mathrm{SO}_{4}$ の濃度比の広い範囲にわたつて，末 ず電流密度と電流効率との関係をしらべた結果, 曲線は 電解液の組成によつて買なるが，何れも電流密度 2 $4.5 \mathrm{~A} / \mathrm{dm}^{2}$ のところに電流効率の最大值が現われた。つ ぎに電解液組成が電流効率に扣よぼす影響をみるため電 流密度 $3 \sim 4 \mathrm{~A} / \mathrm{dm}^{2}$ として, $\mathrm{MnSO}_{4}$ 濃度一定の璂合の $\left(\mathrm{NH}_{4}\right)_{2} \mathrm{SO}_{4}$ 濃度 $(50 \sim 200 \mathrm{~g} / l)$ 之電流効率との関係拈 よび $\left(\mathrm{NH}_{4}\right)_{2} \mathrm{SO}_{4}$ 濃度一定の場合の $\mathrm{MnSO}_{4}$ 濃度 (50 〜200g/l)との関係についてしらべた。その結果, $\mathrm{MnSO}_{4}$ 濃度の兽加は電流効率を堌加させるが， $\left(\mathrm{NH}_{4}\right)_{2} \mathrm{SO}_{4}$ で は逆にそれを低下させることがわかつた。電流効率とい 5 点からいえば $\left(\mathrm{NH}_{4}\right)_{2} \mathrm{SO}_{4}$ 濃度を $50 \mathrm{~g} / l$ 以下まで減 少させることが目的に適うことになるが，安定した電解

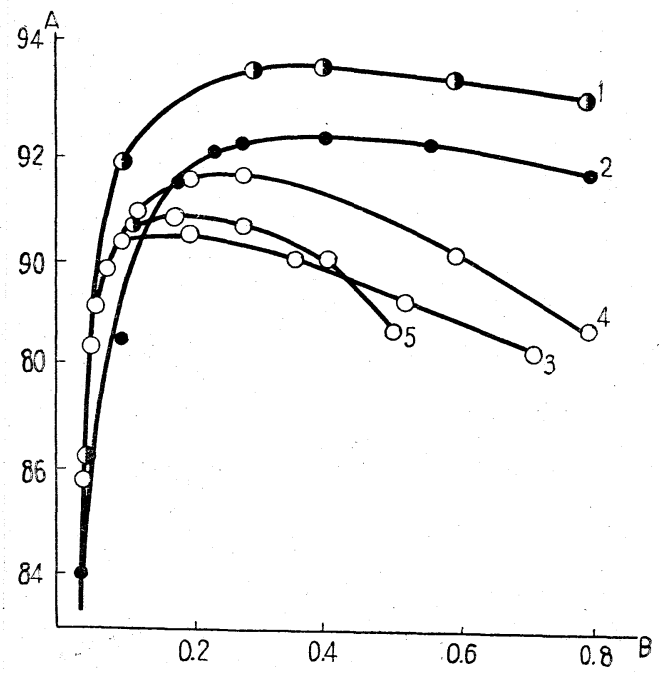

$\mathrm{A}$-電流効率 $\eta(\%), \mathrm{B}-\mathrm{H}_{2} \mathrm{SeO}_{3}(\mathrm{~g} / l)$, 電解液組成 $(\mathrm{g} / l)$, 電流密度 $\left(\mathrm{A} / \mathrm{dm}^{2}\right)$

$\mathrm{pH}$ 值 $1-200 / 75,4,>7 ; 2-200 / 150,4.5,>7 ; 3-100 / 75,3.5,>7$; $4-100 / 75,3.0,>7 ; 5-100 / 75,3.0,>7$

第 1 図 $\mathrm{H}_{2} \mathrm{SeO}_{3}$ 含有量々電流效率との関係
を行らためにはアンモニヤイオンの十分な濃度が必要 で，陰極にそれが $50 \mathrm{~g} / l$ より少なくなると電着物中に水 酸化物がはまりこみ電解が不安定となる。アンモニヤイ オン濃度の増加は電解液の緩衝容量を大さくし, $\mathrm{pH}$ を 7.5〜8.5 まで高めることが出来, $\mathrm{Mn}(\mathrm{OH})_{2}$ の沈着をな くす。 $\mathrm{pH}$ が 7 以下となると $\mathrm{H}_{2} \mathrm{SeO}_{3}$ の還元が激しく起 つて電解液中または電極上に Se を凝集させ，また電流 効率が低下する。結局, 電解液中の $\mathrm{MnSO}_{4}$ は $100 \mathrm{~g} / \mathrm{l}$ $\mathrm{MnSO}_{4} \cdot 5 \mathrm{H}_{2} \mathrm{O}$ よりも少なくしてはならない。それを $200 \mathrm{~g} / l$ より高くしても電流効率は僅かしか増玑しない。 $\left(\mathrm{NH}_{4}\right)_{2} \mathrm{SO}_{4}$ の濃度は $75 \mathrm{~g} / l$ 以下であつてはならない が，多量の $\mathrm{MnSO}_{4}$ を含む電解液 $(200 \mathrm{~g} / l$ の数位 $)$ を 用いる際には $100 \mathrm{~g} / /$ より少なくしてはならない。（N $\left.\mathrm{H}_{4}\right)_{2} \mathrm{SO}_{4}$ 濃度を $150 \mathrm{~g} / \mathrm{l}$ 以上に增加させると電着物の光 沢を失い且つ電流効率を低下させる。これらの結果から 電解液の組成として，200〜 $250 \mathrm{~g} / l \mathrm{MnSO}_{4} \cdot 5 \mathrm{H}_{2} \mathrm{O}$ 抒よ び 125〜 $150 \mathrm{~g} / /\left(\mathrm{NH}_{4}\right)_{2} \mathrm{SO}_{4}$, も台ろん $\mathrm{H}_{2} \mathrm{SeO}_{3}$ 添加の ものが最当よいことがわかつた。

2) $\mathrm{H}_{2} \mathrm{SeO}_{3}$ 濃度が電流効率ならびに電着物に蛙よぼ す影響 : $\mathrm{H}_{2} \mathrm{SeO}_{3}$ 濃叟と電流效率との関係は第 1 図に示 される。図から $\mathrm{H}_{2} \mathrm{SeO}_{3}$ 濃度が $0.2 \sim 0.4 \mathrm{~g} / l$ で電流效 率が最大となることが知られる。電着マンガン中に落ち こむ $\mathrm{Se}$ の量は電解液中の $\mathrm{H}_{2} \mathrm{SeO}_{3}$ 濃度の増加にともな つて直線的に増加 $\left(\mathrm{H}_{2} \mathrm{SeO}_{3} 0.4 \mathrm{~g} / l\right.$ で電着物中 $\mathrm{Se}$ 約 0.9 \%)，また電流密度の増加とともに減少する。これらの ことを考慮すると電解液中の $\mathrm{H}_{2} \mathrm{SeO}_{3}$ 濃度 $0.1 \sim 0.2 \mathrm{~g} / l$, 電流密度 $4 \sim 5 \mathrm{~A} / \mathrm{dm}^{2}$ の時が最適である。電流密度を $5 \mathrm{~A} / \mathrm{dm}^{2}$ 以上にすると陰極に樹状組織が著しく発達し電 流効率が低下する。

結論と乙て, 電解の最䓢条件は電解液成分 $(\mathrm{g} / l)$ : $\mathrm{MnSO}_{4} \cdot 5 \mathrm{H}_{2} \mathrm{O} 200 \sim 250,\left(\mathrm{NH}_{4}\right)_{2} \mathrm{SO}_{4} 125 \sim 150, \mathrm{H}_{2} \mathrm{SeO}_{3}$ $0.1 \sim 0.2$, 電流密度 $4 \sim 5 \mathrm{~A} / \mathrm{dm}^{2}$ である。[文献数 16 ]

(敛木隆三)

\section{8）熔融塩電解によるボロンの製造}

G. T. Miller: Electrolytic Production of Boron (J. Electrochem. Soc. vol. 105 (1959) No. 9, 815 219)

USAEC との契約によりその所有する Model City， N.Y.にある工場を使用して Hooker Chem. Co. が結 晶性の B-10を $40 \mathrm{~kg} /$ 月生産した。B-10 の濃縮は 3 弗 化ボロンーデメチルェーテル錯塩によつたが，その生産 費が \$500/lb 以上という高価なために，それから Bを 製㴔する優秀な方法として愹融塩電解法が研究され，工 業化された。本論交はその研究および工業化における結 論と解明された重要な問題について述べている。

本法は $\mathrm{KBF}_{4}$ と $\mathrm{KCl}$ との混合浴の電解であり，そ の反応は次式で示されることが分つた。 


$$
4 \mathrm{KBF}_{4}+2 \mathrm{KCl} \rightarrow 4 \mathrm{~B}+6 \mathrm{KF}+5 \mathrm{~F}_{2}+\mathrm{Cl}_{2}
$$

電解槽の設計で間題になる点は約 $800^{\circ} \mathrm{C} て ゙ \mathrm{~F}_{2}$ と $\mathrm{Cl}_{2}$ が発生すること, 電解中に愹融塩中の $\mathrm{KF}$ の量が増加 すること，抢よび Bの愹融点が高いために析出した Bが 固体であることである。

電解槽は内径 $23 \mathrm{~cm}$, 高さ $58 \mathrm{~cm}$ の黒鉿製のルッボで これ自体が陽極を兼衴る。黒鉛としては密度が高くて粒 度が小さくかつ灰分の少ないるのが $\mathrm{B}$ の純度を上げるた めに必要である。このルッボは電熱線による外部加熱で 五るためにとの外側をインコネル製外殼によりルツボ壁 童通してくる塩によるニク口ム線の腐蝕を保護してい る。インコネル外殼の腐蝕生成物汇より Bが活染されて もとの不純物の大部分, とくにクロームは析出 B の酸浸

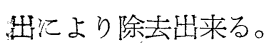

陰極は容易に硼化物を生成しないことと $900^{\circ} \mathrm{C}$ で相 当強度が必要であるために最初銅が選ばれたが寿命が不 定でありから短かいのでモネル合金が実用された。陰極 は中空であり $\mathrm{CO}_{2}$ または $\mathrm{N}_{2}$ で $600 \sim 700^{\circ} \mathrm{C}$ に冷却 ナる。モネル合金は 20 回以上の電解行耐方る。

電解浴表面より上の陰極部分は発生する $\mathrm{F}_{2}$ と $\mathrm{Cl}_{2}$ と による腐蝕をさけるために陰極と浴との境界面上に $\mathrm{H}_{2}$ を直接吹きつけるよ5に設計した $\mathrm{H}_{2}$ 亿よる還元雾围気 保つ。かかる方法によると $\mathrm{H}_{2}$ を方向を定めず萁人 するときょりる約 $1 / 3$ の流速でよい。

電解槽の密封は粉末の $\mathrm{KCl}$ で行い, ボルト締めはし ていないので槽内江空気が入つて $\mathrm{H}_{2}$ が爆発する危険は ない。電解装置はトラニオンの上につくられ，ときどき 電解槽の掃除をするために水平回回転出来るようになつ ている。炉の温度調節はルツボと外殼との閒に方る熱電 対により行われる。

$750 \sim 800^{\circ} \mathrm{C}$ に保持した $\mathrm{KCl}+\mathrm{KF} 11.5 \mathrm{~kg}$ の電解浴 飞 $2.5 \mathrm{~kg}$ の $\mathrm{KBF}_{4}$ を添加し, 陰極を下げて $550 \mathrm{Amp}$ $\left(80 \mathrm{Amp} / \mathrm{dm}^{2}\right), 5 \sim 6 \mathrm{~V}$ で $3.5 \mathrm{hr}$ 電解する。電解条件を 第 1 表衹す。

\section{第 1 表 電解条件}

$\begin{array}{ll}\text { 電解浴 } & 70 \% \mathrm{KCl}, 12 \% \mathrm{KF}, 17.8 \% \mathrm{KBF}_{4}, 0.2 \% \mathrm{H}_{2} \mathrm{O} \\ \text { 温度 } & 750 \sim 800^{\circ} \mathrm{G} \\ \text { 電流 } & 80 \mathrm{Amp} / \mathrm{dm}^{2} \\ \text { 電圧 } & 5 \sim 6 \mathrm{~V} \\ \text { 電力 } & 55 \mathrm{kWh} / \mathrm{kg} \\ \text { 電流効率 } & 74 \% \\ \text { 電解槽雾因気 } & \text { 槽電流 } 550 \mathrm{Amp} \text { の時. } 20 \mathrm{l} / \mathrm{min} \text { の } \mathrm{H}_{2} \text { を陰極付近の電 } \\ & \text { 解浴表面に直接流す } \\ \text { 陰極 } & \text { モネル合金 } \\ \text { 陽極 } & \text { 高密度微粒子黑鉊 }\end{array}$

電解が終ると陰極とその付着生成物 (Bと電解浴との 篠塊物）を引上げて $400^{\circ} \mathrm{C}$ まで空冷し陰極を取り出し， 次に水冷して陰極と付着生成物を分離しやすくする。生 成物は口ッドミルで -100 mesh に粉䂶後, 水拉よび酸 浸出して精製し, 水洗, アルコール洗滌, 乾燥後ポリエ
チレンの袋に封スする。

電解浴の組成は Bの収率と純度に重大心影響がある。 $\mathrm{KCl}: \mathrm{KF}$ の重量比が 2.5:1 以下であるとBの収率が 悪いので 3:1〜6:1 に保つ。屯た新らしい $\mathrm{KCl}$ と $\mathrm{KBF}_{4}$ とを使用する第 1 回の電解では $\mathrm{B}$ の収率孔純度も 低いが兄孔らを補給した第 2 回以後つ電解では収率, 純 度ともに良好である。全電解浴を廃㲤して全部を新らし い電解浴にするまでに 30４0回電解出来る。化学的純 䊉な $\mathrm{KCl}$ の代りに工業的品位の $\mathrm{KCl}$ を使用すると $\mathrm{B}$ の純度が下る。浴中の不純物, 添加阂の影響を第 2 表に 示す。

第 2 表 電解浴中の不純物, 添加剤の影響

\begin{tabular}{|c|c|c|c|c|c|c|}
\hline \multirow{2}{*}{ 添 加 鼡 } & \multirow{2}{*}{ 重量\% } & \multirow{2}{*}{$\mathrm{B} \%$} & \multirow{2}{*}{ 収 率 \%ó } & \multicolumn{2}{|c|}{ 添加剂のない場合 } & \multirow{2}{*}{ 電解槽 No. } \\
\hline & & & & B $\%$ & 収率\% & \\
\hline $\mathrm{K}_{2} \mathrm{SO}_{4}$ & 0.18 & 95.0 & 81.5 & 94.7 & 75.5 & 1 \\
\hline $\mathrm{CaCl}_{2}$ & 0.72 & 93.0 & 陰敪より落下 & 92.8 & 87.8 & 2 \\
\hline $\mathrm{VOSO}_{4}$ & 0.47 & 89.0 & 43.0 & 94.7 & 75.5 & 1 \\
\hline $\mathrm{AlF}_{3} \cdot \mathrm{H}_{2} \mathrm{O}$ & 0.40 & 94.7 & 86.8 & 95.0 & 87.0 & 3 \\
\hline $\mathrm{Al}$ & 0.10 & 95.5 & 83.5 & 94.7 & 75.5 & 1 \\
\hline $\mathrm{H}_{2} \mathrm{O}$ & 0.18 & 95.8 & 88.0 & 94.7 & 75.5 & 1 \\
\hline $\mathrm{Ni}$ & 0.28 & 50.9 & 73.3 & 94.7 & 75.5 & 1 \\
\hline Inconel & 0.28 & 88.7 & 59.2 & 94.7 & 75.0 & 1 \\
\hline
\end{tabular}

な和製品のBは数力月間賠蔵するとその品位が 2 2 $3 \%$ 低下することがわかつた。これはBがゲッターとして作 用して空気中のガスを吸着するためである。それでフル ゴンで清浄した真空师よりむ酸素で清浄した $100^{\circ} \mathrm{C} の$ 真空炬内で短時間覞科して乾燥し Bの表面に非常にうす い酸化物の保護被膜を形成させ $\mathrm{B}$ を不衝態とするとよい ことが認められた。粉砕した製品は - 100mesh 100\%， そのうちー200mesh 90\%,-325mesh 20\%でありX線 回析によると +325 mesh の部分㤬晶性であつた。B の純度は 94〜96\% であり，主な不純物は $\mathrm{C}, \mathrm{Ni}, \mathrm{Cr}$, $\mathrm{Si}, \mathrm{Mg}, \mathrm{K}, \mathrm{H}_{2} \mathrm{O}, \mathrm{O}_{2}$ 㧊よび $\mathrm{Cu}$ である。

な和著者によりBの愹融塩電解に関し下記交献が発表 されている。

(浅野楢一郎)

G. T. Miller, USAEC Report NYO-1265, May 31, 1956; USAEC Report HEG-79, April 22, 1957; USAEC Report HEC-88, April 18, 1958; USAEG Report HEC-89, May 7, 1958.

\section{9) ボロンカーバイド}

M. Bouchet: Le Carbure de Bore (Jl. Four Electrique, 64, (1959), No. 1, 23 15)

ボロンカーバイドは Moissan の研究以来, その硬度 と耐熱性が優れていることが知られており, 最近ジェッ トエンジン材料としての研究がさかんに行われている。 またBの同位元素のうち $\mathrm{B}^{11}$ は中性子を漂とんど透過 させるのに反し， $\mathrm{B}^{10}$ 性そい中性子に対して大きい中 性子吸収断面積を有して括り，これらの性質を組み合せ て原子力航空機材料としてボロンカーバイドが利用され 
るのも近い将来であるう。

\section{(I) 性 質}

物理的性質

Knoop 硬度 $2250 \sim 2260$, 密度 2.51 , 融点 $2450^{\circ} \mathrm{C}$, 沸点 $3500^{\circ} \mathrm{C}\left(\mathrm{B}_{6} \mathrm{C}\right.$ 汶して $)$, 熱伝導度 $0.065 \mathrm{cal} \cdot \mathrm{g} / \mathrm{cm}^{2} /$ ${ }^{\circ} \mathrm{C} / \mathrm{cm}$, 膨脹係数 $4.5 \cdot 10^{-6}$, 中性子吸収断面積 $82 \mathrm{~cm}-\mathrm{I}$, 比熱 $0.443 \mathrm{cal} / \mathrm{g} /{ }^{\circ} \mathrm{C}$, 耐圧強度 $20,000 \mathrm{~kg} / \mathrm{cm}^{2}$, 電気抵抗 $0.30 \sim 0.80 \mathrm{ohm} / \mathrm{cm}$

化学的性質

ボロンカーバイドの化学式は $\mathrm{B}_{4} \mathrm{C}$ として示されるが， 化学量論的学化合物ではなく，金属間化合物に類似して いる。すべての酸, 塩素酸カリ，アルカリ溶液に対して 抵抗力があり $1000^{\circ} \mathrm{C}$ 以下で塩素, 酸素により徐々に 浸されるが，空気中で涊安定である。

\section{(II) 製 造 法}

\section{1. 元素の直接結合}

かつて Moissan はアーク怗を用いて $\mathrm{B}_{6} \mathrm{C}$ を得た。

これに要する硼素は多分, $\mathrm{H}_{2}$ 気流中で加熱カーボンフ ィラメント上に塩化研素を熱分解させて得られたものと 思われる。この方法沈 $\mathrm{B}_{4}{ }^{10} \mathrm{C}$ の製造に際し注目すべき 方法である。

また硼素次弗化研素の金属アルカリ還元によつても得 ら礼る。

\section{2. 電気炉による酸化物の還元}

炭素抵抗炉をさはアーク炉を用いる。カルシウムカー バイドが混合することがあるが，これは生成物に水を作 用させて分離できる。

3. 拡散法

鉄鋼の表面沙ら硼素を拡散させてボロンカーバイドを つくることもできる。

\section{（III）.成形および加工}

ボロンカーバイドはその物理的性質抢よび中性子断面 積つ特異性が利用されまた他の研化物の原料にもなる。 成形の方法としてはａ）高温成型（アルゴン気流中， 黒鉛また怯窒化硼素の型を使用)，ｂ）常温成型後焼結， c) 金属 (Al) をバインダーとして成型, d) $\mathrm{SiC}, \mathrm{TiB}_{2}$, $\mathrm{TiC}, \mathrm{Co}, \mathrm{Fe}, \mathrm{Ni}, \mathrm{Cr}, \mathrm{Ti}$ とともにサーメットとして使 用，e）珪酸ソーダ，硼酸，ゴム，樹脂，ポリエチレン 等を使用乙て成型，f）特殊吹管を用、金属面淁着， g）ボロンカーバイドによる金属の接合等が核る。

\section{(IV) 用 途}

1. 研摩剤 ダイヤモンドの切削!と使用できる。

2. 工具 $10 \%$ SiC を配合したボロンカーバイド はきわめて優れた性質を示した。

3. 種々の機械部品 いちじるしい摩粍をうける部品 に使用され，鋼に碚素を添加して璌化させることも可能 で女る。

4. 耐熱耐摩粍部品，而敨性とサーマルショックに対 する大きい抵抗性を利用して，羽口，タービン部品に用 いられる。使用に際し表面の酸化を避けることが必要で

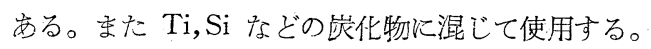

5. 原子炉用材料 天然掂嘅素は $\mathrm{B}^{10}$ を $18.8 \%$ 含 み，これから製造したボロンカー・バイドは耐熱材料であ り且つ掘い中性子をよく昅収する。

$$
\mathrm{B}^{10}+\mathrm{In}=\mathrm{Li}^{7}+\mathrm{He}^{4}+2.34 \mathrm{MeV}
$$

$\mathrm{B}^{10}$ の中性子吸収断面積法 3950 バーンであり，一方 $\mathrm{B}^{11}$ はほ亡んど中性子を吸収しない。ボロンカーバイド のこの性質を利用して，棒，円板，管などの形沉する または不銹鋼のさやに入れて原子炬の制御棒に使用し， またアルミニゥム中に分散させたり (Boral)，合成樹脂 内に分散させる研究も行ないれている。

また三弗化喟素を用いて同素元素の分離を行なうこと も可能である。長時閒の分離により $\mathrm{B}^{10}$ と $\mathrm{B}^{11}$ が得ら れる。

$\mathrm{B}_{4}{ }^{10} \mathrm{C}$ 沖中性子吸收剤と乙て非常に大きい効力を有 乙，航空機用原子炉の防御材料と乙て注目される。ま た $\mathrm{B}_{4}{ }^{11} \mathrm{C}$ は $\mathrm{Zr}_{4} \mathrm{~B}_{2}{ }^{11}$ の原料供せられ, $\mathrm{Zr}_{4} \mathrm{~B}_{2}{ }^{11}$ は中性 子を通過させ且つ優秀な的熱材料であるので，高温で作 用する原子炉の材料使用することができる。

ボロンカーバイドの商品としての価格は現在では出発 原料の希有性によるものではなく，同位元素分離の困難 性によるものである。そのため工業的な新用途を閉発す べく種々の研究が行われている。(文献 30 , 特許 30 )

（近藤良夫） 